\title{
HAK IJBAR WALI NIKAH DALAM KAJIAN HISTORIS FIQH SHÂFI'Î
}

\author{
Syaiful Hidayat \\ Institut Agama Islam Bani Fattah Jombang, Indonesia \\ E-mail: alaminilman313@gmail.com
}

\begin{abstract}
Is currently still found practice of coercion marriages by the guardian (especially father) to his daughter. The imposition of this marriage is more commonly referred to as hak ijbar. Anvil used is an understanding of hak ijbar the inherent certainty for a guardian over her daughter. Are Syafi'i schools seen as dominant calling for hak ijbar based on the behavior Apostle who married 'Aisyah at age so young and in the absence of discussions between $A b u$ Bakr and 'Aisyah be a sign of existence bak ijbar. However, as the Indonesian people, beside figh also must submit and obedient the laws and all regulations thereunder, including the Islamic Law Compilation (KHI). In Article 72 KHI described; The revocation of a marriage is a marriage without a guardian or trustee executed by unauthorized and marriage carried out by force. This means the hak ijbar not allowed because it constitutes coercion. This issue is interesting to examine the social side, especially the social history of women at the time of priest Syafii life. It aims to determine the general condition and position of women in the social institution that has its historical position which will then be used as a prediction projective.
\end{abstract}

Keywords: Hak Ijbar, Guardian, Historical Study, Syafi’i 


\section{Pendahuluan}

Saat ini masih dijumpai praktik pemaksaan perkawinan oleh wali (khususnya ayah) terhadap anak perempuannya. Pemaksaan perkawinan ini lebih sering disebut sebagai hak Ijbar. Landasan yang digunakan adalah pemahaman akan hak Ijbar yang melekat secara mutlak bagi seorang wali atas anak perempuannya. Adalah madzhab Syafi'i yang terlihat begitu dominan menyerukan hak Ijbar ini berdasarkan atas perilaku Rasul yang menikahi 'Aisyah. Pada saat terjadi perkawinan 'Aisyah pada saat itu dinikahkan oleh Abu Bakar ra. Usia yang begitu belia dan tidak dimungkinkannya terjadi diskusi antara Abu Bakar dan 'Aisyah menjada tanda akan eksistensi dari adanya hak Ijbar itu sendiri.Namun demikian, sebagai masyarakat muslim Indonesia, disamping ada fikih di satu pihak, khususnya madzhab Syafi'i, di pihak yang lain juga harus tunduk dan taat terhadap peraturan perundangundangan dan seluruh peraturan yang berada di bawahnya, termasuk dalam katagori ini adalah Kompilasi Hukum Islam (KHI).dalam Pasal 72 misalnya,menjelaskan bahwa "Batalnya perkawinan adalah perkawinan tanpa wali atau dilaksanakan oleh wali yang tidak berhak dan perkawinan yang dilaksanakan dengan paksaan”. Hal ini berarti bahwa hak ijbar wali dalam Pasal 72 KHI, tidak diperbolehkan karena dalam ijbar terdapat unsur paksaan. Berangkat dari persoalan inilah tulisan ini kami tulis, namun bukan untuk melihat hak Ijbar secara legal-normatif namun lebih pada sisi social kemasyarakatan, khususnya sejarah sosial tentang perempuan pada saat Imam Syafi'i hidup. Hal ini bertujuan untuk mengetahui secara umum kondisi dan posisi perempuan dalam pranata sosial sehingga dapat ditemukan posisi kesejarahannya yang selanjutnya akan digunakan sebagai prediksi proyektif.ada dua hal pokok dalam tulisan ini yaitu konsep ijbar dalam pandangan imam Syafi'i dan keadaan social perempuan pada saat imam Syafi'i hidup

\section{Hak Ijbar Menurut Imam Al-Syafi'i}

Hak ijbar adalah hak ayah atau kakek untuk menikahkan anak perempuannya, baik yang sudah dewasa maupun masih berusia muda, tanpa harus mendapatkan persetujuan atau izin terlebih dahulu dari anak perempuan yang akan dinikahkan tersebut, asalkan ia bukan seorang janda. ${ }^{1}$ Berdasarkan ketentuan ini, para wali memiliki hak untuk

1 Abdurahman al-Jaziri, Kitâb al-Fiqhu 'alâ Madhâbib al-Arba'ab (Beirut: Dar al-Fikr, 1999), Vol. 4, 24. 
mengawinkan anak perempuannya yang masih di bawah umur, meski tanpa persetujuan yang bersangkutan.

Perlu dikemukakan di sini bahwa dalam mazhab Syafi'i dikenal istilah ijbar bagi wali mujbir. Wali mujbir adalah orang tua calon mempelai perempuan, yang dalam aliran Syafi'i ialah ayah, atau kakek apabila ayahnya tidak ada. ${ }^{2}$ Walaupun demikian, hak ijbar ayah atau kakek tidak serta merta dapat dilaksanakan dengan sekehendak hatinya. Ulama' madzhab Syafi'i mengatakan bahwa untuk bisa mengawinkan anak lakilaki di bawah umur disyaratkan adanya kemaslahatan, sedang untuk anak perempuan diperlukan beberapa syarat, antara lain (1) Tidak adanya permusuhan yang nyata antara anak perempuan dengan walinya; (2) Tidak ada permusuhan yang nyata natara dia dengan calon suminya; (3) Calon suami harus sekufu'; (4) Calon suami harus memberikan maskawin yang pantas. ${ }^{3}$

Tentang masalah ijbar, imam al-Syafi'i menyandarakan pendapatnya pada sebuah hadis yang menceritakan perkawinan Rasul dengan 'Aisyah putri Abu Bakar ra.:

تَزَوَّجنِنى رَسُولُ اللَّهِ -صلى الله عليه وسلم- لِسِتِّ سِنِينَ وَبَنَى بِى وَأَنَا بِنْتُ تِنْعِ

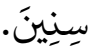

Artinya: "Rasul menikabiku pada saat usiaku 6 tahun, dan bidup bersamaku pada usia 9 tahun." ${ }^{4}$

Rasulullah saw menikah deangan 'Aisyah setelah Khadijah, isteri pertama Rasul, meninggal dunia, yakni tahun ke-3 (tiga) sebelum hijrah. ${ }^{5}$ Jika dikatakan dalam hadits bahwa 'Aisyah berumah tangga dengan Rasul pada usia 9 tahun, berarti saat itu 'Aisyah baru berada di kota Madinah pada tahun ke 3 Hijriyah. Al-Nawawi dalam menjelaskan hadits di atas mengemukakan bahwa tidak perlu izin bagi ayah untuk mengkawinkan anak perempuan yang masih kecil, sebab anak yang masih kecil tidak mungkin memberikan izin. Tentu pertimbangan yang digunakan oleh

\footnotetext{
${ }^{2}$ Wahbah al-Zuhayli, Al-Fiqhu al-Islâmî wa Adillatuh (Beirut: Dar al-Fikr, 1997), Vol. 7, 6695.

3 Ibid., 29.

4 Muslim b. Hajjaj al-Naysaburi, Sabîh Muslim (Beirut: Dar al-Kutub al-'Ilmiyah, 2013), Vol. 1, Indeks 1422, 604.

${ }^{5}$ Ahmad b. Hajar al-'Asqalani, Fatḥ al-Bâri Syarh Șabîh Muslim, (Beirut: Dar Ma'rifah, 1379 H.), Vol. 9, 26.
} 
ayah adalah untuk kemashlahatan anak gadis yang dikawinkannya. ${ }^{6}$ Masih terkait hadits pernikahan Rasul dengan 'Aisyah di atas, imam alSyafi'i menyatakan:

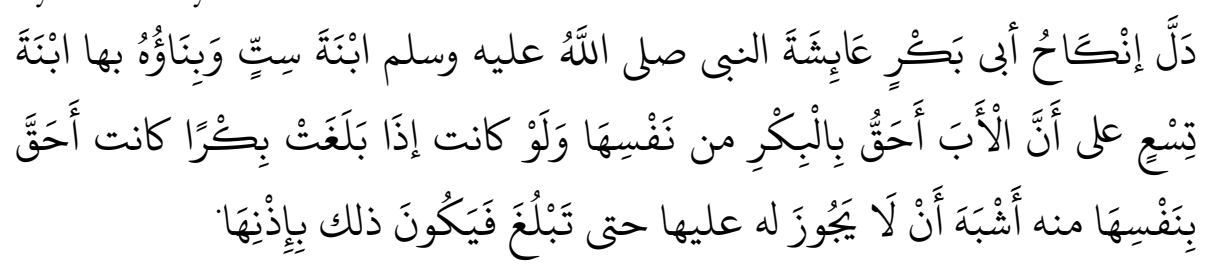

Artinya: 'Dari pernikahan 'Aisyah dengan Nabi saw oleh Abu Bakar ra disaat masib usia 6 tahun dan berumah tangga dengan Rasul pada saat 9 tabun menunjukkan babwa ayah lebib berhak atas diri gadis melebibi hak dirinya sendiri; sebab seandainya anak perempuan yang telab mencapai usia gadis lebib berbak atas diriny sendiri daripada ayahnya, itu sama balnya bagi ayah tidak diperbolebkan menikabkanny sampai ia mencapai usia baligh sehingga perkawinannya baru dapat diselenggarakan atas i zinnya." 7

Dari pernyataan imam al-Syafi'i di atas diketahui bahwa seorang wali lebih berhak atas diri anak gadisnya, khususnya yang berkaitan dengan perkawinan, selama memang belum mencapai usia dewasa atau baligh. Hal ini dipandang wajar, sebab anak dalam usia sebelum baligh seluruh tindakan keperdataannya dilimpahkan kepada walinya, hal ini sebab anak tersebut belum dipandang sebagai cakap hukum.

Lebih lanjut, dalam hal penentuan usia baligh, sehingga seseorang dipandang cakap hukum, imam al-Syafi'i menyatakan bahwa:

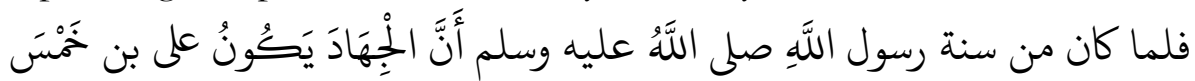

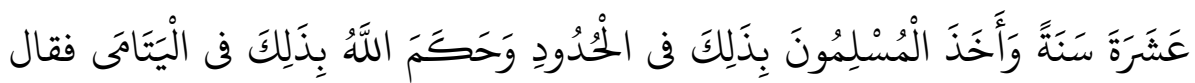

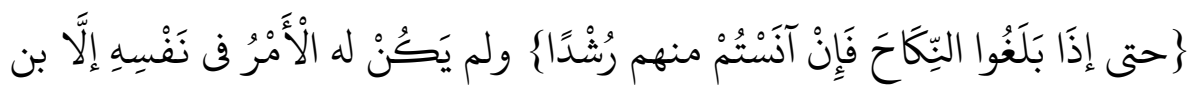

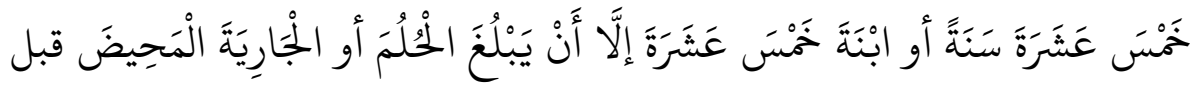

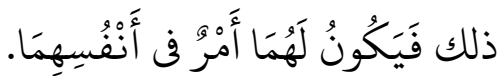

Artinya: "Ketika ketentuan yang menyatakan bahwa kewajiban jibad dibebankan atas anak usia lima belas tabun itu menjadi sunnah Rasul dan hal ini diambil oleb kaum muslimin sebagai batas ketentuan serta

${ }^{6}$ Abu Zakariya Yahya b. Syaraf al-Nawawi, Syarh Șahîh Muslim, (Beirut: Dar Ihya' Turats al-Arabi, 1392 H.), Vol. 9, 206.

${ }^{7}$ Muhammad b. Idris al-Syafi'i, Al-Umm, CD al-Maktabah al-Syamilah, Vol. 5, 17. 
Allah swt menetapkannya dalam hal anak-anak yatim; Allah swt berfirman "samapi mereka cukup umur untuk kawin. Kemudian jika menurut pendapatmu mereka telah cerdas (pandai memelihara harta)8" dan tidaklah ada baginya perintah (yang berlaku) untuk dirinya sendiri kecuali ia adalah anak laki-laki yang telah mencapai usia lima belas tabun, atau anak perempuan usia lima belas tahun; terkecuali bagi yang sudah mimpi basah atan gadis yang haid sebelum usia lima belas tabun maka bagi keduanya berlaku perintah (yang berlaku) untuk mereka berdua."

Dengan demikian jika terdapat seorang anak perempuan yang belum pernah mengeluarkan haid dan belum mencapai usia 15 (lima belas) tahun atas dirinya berlaku hak ijbar oleh walinya, sehingga wali boleh menikahkannya dengan lelaki siapapun tanpa harus meminta persetujuannya. Ketentuan ini berbeda halnya jika ternyata anak perempuan yang akan dinikahkan telah mencapai usia bikr (gadis). Dalam hal ini al-Syafi'i mengambil hujjah dari hadis Rasul yang berbunyi:

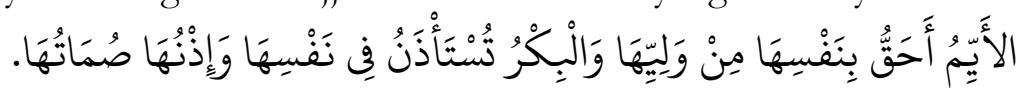

Artinya: 'Janda lebih berbak tentang dirinya sendiri, sementara gadis dimintai ižin dalam dirinya dan ižinnya adalah diamnya.,"10

Tentang hadits ini imam al-Syafi'i memberikan analisis dengan menyatakan bahwa:

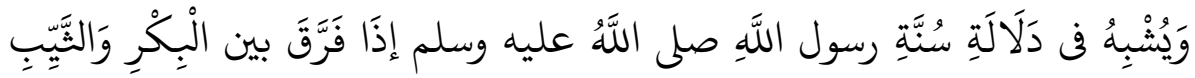

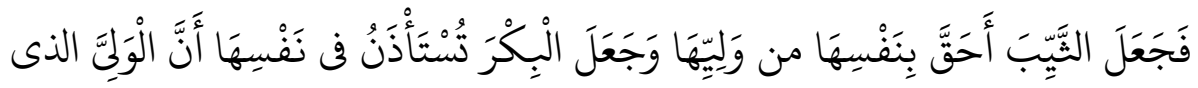

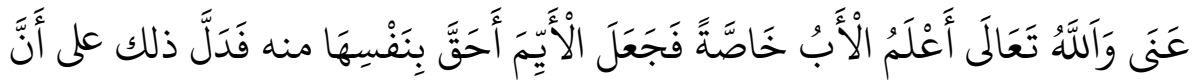

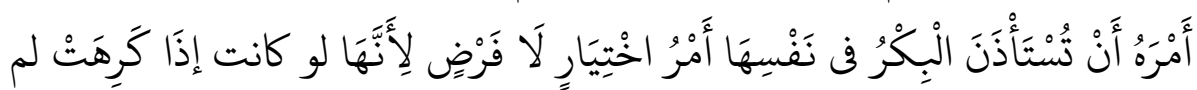

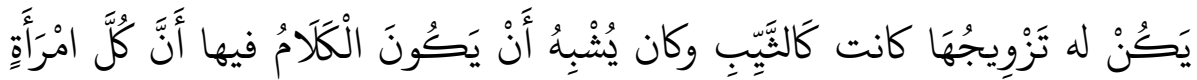

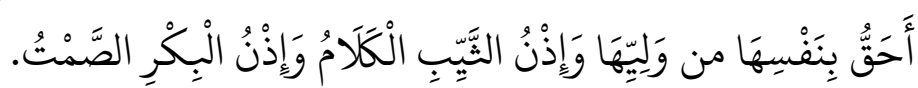

Artinya: "Petunjuk sunnah Rasul ketika membedakan antara gadis dan janda; yakni janda lebib berhak atas dirinya sendiri dibanding walinya, dan menjadikan anak gadis harus dimintai iæin dalam dirinya, memberi

8 Departemen Agama RI, Al-Qur'an dan Terjemahannya (Bandung: CV Penerbit J-Art, 2014), 78.

${ }_{9}$ Ibid.

10 Muslim, Saḅ̧̌̂ Muslim......, Indeks 1421, 604. 
keserupaan bahwa wali -sebagaimana yang dikendaki- yakni khusus bapak -wallabu a'lam- dan menjadikan janda lebih berbak dengan dirinya sendiri disbanding walinya. Hal ini menunjukkan babwa perintah untuk meminta iæin kepada gadis dalam dirinya merupakan perintah piliban bukan perintah wajib. Sebab jika seandainya anak. gadis tidak mau kepada calon suaminya sehingga bagi wali tidak boleh mengkawinkannya, maka anak status anak gadis seperti janda. Dan dengan demikian sama halnya artinya seluruh perempuan sama-sama lebih berbak dengan dirinya sendiri daripada walinya; izinnya janda adalah dengan perkataan sedangkan irinnya gadis adalah dengan diam" $" 11$

Penjelasan imam al-Syafi'i di atas merupakan lanjutan pernyataan tentang anak perempuan (non janda) seandainya telah mencapai usia gadis (bikr), maka bagi seorang wali dianjurkan untuk meminta izin jika ingin mengawinkannya, sekalipun hal ini tidak berupa kewajiban.

Dari titik ini imam al-Syafi'i masih bersikukuh tentang adanya hak ijbar bagi seorang wali. Satu-satunya penyebab hilangnya hak ijbar seorang wali, dengan demikian, hanyalah ketika perempuan berstatus sebagai janda. Kriteria janda menurut ketetapan imam al-Syafi'i adalah:
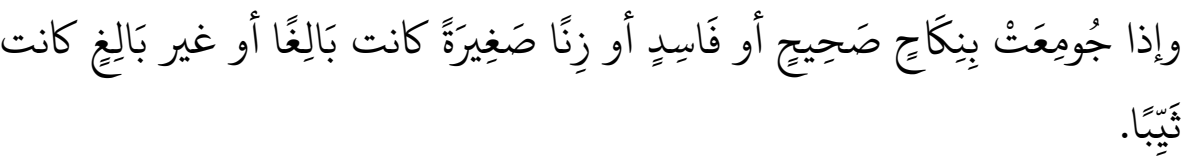

Artinya: 'Ketika seorang perempuan telah di jima' dengan nikah yang sah ataupun fasid atau karena zina, baik perempuan tersebut masib kecil, sudah baligh atau belum maka statusnya adalah janda. "12

Dari sini diketahui bahwa penentuan status janda adalah karena telah berhubungan badan dengan laki-laki, baik melalui perkawinan yang sah ataupun jalan illegal. Baik perempuan tersebut masih kecil ataupun sudah dewasa.

Kesimpulan tentang hak Ijbar oleh wali atas anak dalam hal perkawinan, menuru Imam al-Syafi'i sebagaimana yang telah dikemukakan di atas adalah:

Pertama, Jika anak perempuannya telah dijima' maka walinya tidak boleh mengkawinkannya kecuali ada izin secara lisan dari yang bersangkutan;

11 Al-Syafi'i, Al-Umm..., 18.

12 Ibid. 
Kedua, Jika anak perempuannya masih gadis dan sudah baligh, maka bagi wali dianjurkan untuk meminta izin kepadanya jika ingin mengkawinkannya;

Ketiga, Jika anak perempuannya masih gadis dan belum baligh, maka bagi wali langsung dapat mengkawinkannya meski tanpa izin terlebih dahulu.

\section{Kondisi Sosial Perempuan Pada Masa Imam Syafi'i}

Imam Syafi'i dilahirkan pada tahun 150 H., di kota Ghazah (nama suatu kampong termasuk daerah Syam wilayah Asqalan) bertepatan dengan meninggalnya imam Abu Hanifah, pendiri mahzhab Hanafi. Sebagian sejarawah menyebut pada hari dilahirkannya Imam al-Syafi'i di hari itu pula imam Abu Hanifah meninggal. Namun pendapat ini ditolak oleh Abu Zahrah. Menurutnya pendapat ini sengaja dihembuskan agar tercipta opini publik bahwa tidak ada kekosongan imam bidang fikih di muka bumi ini. ${ }^{13}$

Imam Syafi'i hidup pada masa yang dikatakan oleh sejarawan sebagai zaman keemasan Islam, dia hidup pada masa Dinasti Abbasiyah. Keemasan peradaban Islam yang tercermin, terutama dalam bidang ilmu pengetahuan. Penerjemahan terhadap hasil karya masa Khalifah Harun al-Rasyid yang kemudian dilanjutkan oleh Khalifah al-Ma'mun. Karyakarya Yunani yang diterjemahkan tersebut meliputi berbagai disiplin dan lain-lain, namun sayang kemajuan tersebut kurang dibarengi dengan pemberian ruang bagi perempuan untuk mengaktualisasikan dirinya.

Situasi politik dalam negeri pada awal periode Dinasti Abasiyyah, atau tepatnya pada masa Imam al-Syafi'i sangat mencolok perbedaannya dengan periode khalifah Bani Umayyah. Jika pada Dinasti Bani Umayyah orang-orang Arab memegang posisi penting dalam pemerintahan, maka ketika Dinasti Abasiyyah jabatan-jabatan strategis Negara banyak diduduki oleh orang-orang Persia, khususnya Khurasan sebagai bentuk imbal jasa atas dukungan politik yang diberikannya sehingga dapat menggulingkan pemerintahan yang sah pada saat itu. ${ }^{14}$ Para ahli sejarah mencatat bahwa kuatnya pengaruh politik orang-orang Persia dalam pemerintahan berakibat tergusurnya pengaruh orang-orang Arab.

\footnotetext{
13 Muhammad Abu Zahrah, Târikh Madhâhib al-Islâmiyyah (Kairo: Dar Fikr al-Arabi, 2009), 430.

14 Ahmad Nahrawi Abdus Salam, Al-Imâm al-Syâfi' î fi Madhâbihi al-Qadîm wa al-Jadîd, terj. Usman Sya'roni, (Jakarta: Penerbit Hikmah, 2008), 69.
} 
Pengaruh bangsa Persi yang begitu kuat menjadikan tradisi dan budaya Persia menjadi lekat dalam gaya hidup Dinasti 'Abbasiyyah sehingga kehidupan masyarakat Islam layaknya kehidupan masyarakat Persia namun masih mempunya kemiripan dengan gaya masyarakat Arab. Para penguasa Bani Abbasiyah mulai terpengaruh dengan gaya hidup mewah dan arogan. Kemegahan istana-istana dan keindahan taman bunga milik para khalifah dan para pejabat menggambarkan sisi materialisme kehidupan mereka. Bukan hanya itu, di istana pun sering dipenuhi dengan gadis-gadis cantik, para penyanyi dan para pelayan. Menurut satu sumber, disebutkan bahwa harun al-Rasyid memiliki 2.000 penyayi dan pelayan minum yang berpaikan indah dan berkalung mutiara. ${ }^{15}$ Pengaruh kesukuan primitif yang menjadi pola organisasi sosial Arab paling mendasar runtuh pada Dinasti Abasiyah, yang didirikan dari berbagai unsur asing. Bahkan dalam persoalan memilih isteri dan ibu untuk anak-anak mereka, para khalifah tidak menjadikan darah keturunan Arab sebagai patokan. Diantara keluarga Abbasiyyah hanya tiga Khalifah yang terlahir dari ibu yang merdeka Abu al-Abbas, al-Mahdi dan alAmin. ${ }^{16}$

Kaum perempuan masa Daulah Abbasiyah terbagi menjadi tiga, yakni golongan kelas khusus, umum, dan budak. Perempuan kelas khusus adalah mereka yang termaasuk dalam keluarga Istana, bangsawan, keluarga Bani Hasyim, menteri, gubernur, dan yang sejajar dengan itu. Untuk kalangan kelas khusus ini, mereka banyak terlibat dalam urusan politik di Istana. Perempuan kelas umum adalah para seniman, fuqaha pujangga, pengusaha, industrialis, dan petani. Peran perempuan dalam golongan ini lebih dominan pada bidang agama, pendidikan dan ilmu pengetahuan, serta seni dan sastra. Perempuan budak adalah mereka yang tinggal di dalam harem. Kebanyakan dari mereka mengembangkan kemampuan dalam seni dan sastra. ${ }^{17}$

Pada masa awal Dinasti Abasiyyah, kaum perempuan kelas khusus cenderung menikmati tingkat kebebasan yang sama dengan kaum lelaki. Pada masa itu banyak perempuan mengukir prestasi dan berpengaruh di pemerintahan, seperti Kayzuran isteri al-Mahdi dan ibu al-Rasyid. ${ }^{18}$ Berbeda dengan perempuan-perempuan biasa, para perempuan elite mempunyai nilai tawar dengan para pria, mereka bisa menawarkan

\footnotetext{
15 Ibid.

16 Philip K. Hitti, History Arabs, terj. R. Cecep Lukman Yasin dan Dedi Slamet Riyadi, (Jakarta: Serambi, 2008), 414.

${ }^{17}$ http://digilib.uin-suka.ac.id, diakses pada tanggal 24 Januari 2015.

${ }^{18}$ Philip K. Hitti, History Arabs..., 414.
} 
syarat-syarat perkawinan kepada calon suami mereka. Orang pria yang melalakukan hal ini sangat sedikit karena mereka lebih suka mencari perempuan dengan membelinya di pasar-pasar untuk dijadikan selir atau budak mereka. Mereka tidak mau terikat dengan perkawinan yang memiliki syarat-syarat dan kewajiban-kewajiban yang mengikat antara mereka setelah menjadi suami isteri, bahkan setelah keduanya meninggal dunia, yaitu hak-saling mewarisi antara keduanya. Demikian sebagaimana penjelasan Leila Ahmed dan dicuplik Zaenul Mahmudi. ${ }^{19}$

Perempuan-perempuan biasa pada pada masa ini mempunyai nasib yang tidak jauh berbeda dengan barang dagangan, mereka diperdagangkan di pasar-pasar untuk dijadikan budak pemuas nafsu para lelaki berjuis, lelaki keluarga istana dan para para Khalifah. Pada masa ini perempuan bukan pencipta teks untuk menggambarkan dirinya yang sebenarnya. Teks-teks tentang perempuan tersebut diciptakan oleh orang-orang laki-laki yang secara alamiah terpengaruh dengan budaya dan masa yang sangat patriarkis, sehingga penggambaran mereka terhadap kondisi perempuan mengenai kiprahnyadalam kehidupan dan relasi mereka dengan kaum pria sangat dimungkinkan terjadi kecenderungan patriarkis dalam penulisannya karena pencipta teks-teks pada waktu itu hampir semuanya berjenis kelamin laki-laki. Pada masa ini tidak banyak informasi yang jelas dari buku-buku yang ditulis oleh para sejarawan mengenai sikap dan kiprah para perempuan serta posisinya didalam masyarakat. Leila Ahmed, sebagaimana disebutkan oleh Zaenul Mahmudi, mengemukakan bahwa perempuan pada masa Abbasiyah tidak ada yang berkiprah dalam urusan sentral masyarakat. Sejak itu, perempuan-perempuan elite dan kelas-kelas borjuis hidup dalam pingitan. Perempuan-perempuan tersebut tinggal di harem-harem (bagian rumah yang terpisah untuk kaum perempuan di negeri Arab) yang terisolir dari kehidupan luar. Mereka ditugaskan untuk melayani nafsu seksual para pria kerajaan dan para pria kaya. Pada masa ini, kaum elite lelaki Muslim memang mempunyai kesempatan untuk mendapatkan selir yang banyak, bahkan sudah menjadi norma budak perempuan. Para elite laki-laki Muslim akan merasa malu apabila tidak memiliki isteri lebih dari satu dan selir yang banyak. ${ }^{20}$ Khalifah memperoleh budak perempuan, kadang-kadang sebagai bagian dari rampasan perang dalam penaklukan, ditawarkan oleh salah seorang gubernurnya, hadiah dari orang yang ingin berbuat baik dengan khalifah, dibeli dari pasar selir, ketika budak tersebut

${ }_{19}$ Zaenul Mahmudi, Sosiologi Fikih Perempuan, (Malang: UIN Malang Press, 2009), 83.

${ }^{20} \mathrm{Ibid}, 82$. 
mempunyai bakat-bakat istimewa. ${ }^{21}$ Penjualan budak perempuan sebagai komoditas dan objek seksual merupakan fenomena sehari-hari yang bisa dijumpai pada masa Abbasiyah. Secara umum budak-budak perempuan tersebut dijual untuk dipekerjakan dalam rumah tangga, tetapi ketika para pedagang budak melihat ada budak perempuan yang cantik dan potensial, maka budak tersebut dikarantina terlebih dahulu untuk dirawat agar tampak lebih cantik dan diajarkan berbagai macam keahlian. Guna meningkatkan mutu dan nilai jual budak perempuan, lembaga pendidikan untuk budak perempuan merupakan suatu lembaga yang dapat menarik keuntungan besar kepada orang-orang yang terlibat didalamnya. Pendidikan untuk budak ini menonjol pada masa Khalifah al-Mahdi dan Khalifah al-Manshur. Ibrahim al-Mausili adalah seorang guru yang senantiasa membantu kedua Khalifah tersebut dalam menyelenggarakan pendidikan ini. Al-Mausili mengajarkan tentang musik, puisi dan nyanyian Arab kepada para budak perempuan tersebut. Budak perempuan yang mempunyai keahlian dalam bidang musik dan olah vokal berharga tinggi dan mereka dijual tidak di pasar budak, tetapi di pasar selir yang diminati oleh keluarga istana dan keluarga bangsawan. ${ }^{22}$ Dengan adanya pendidikan untuk para budak perempuan sebelum dijadikan sebagai selir, pada masa ini disinyalir ada beberapa kategori pekerjaan yang sering diminati oleh kaum perempuan. Perempuanperempuan yang telah dibeli di pasar selir diletakkan di harem-harem untuk melayani tuannya secara seksual, mereka mengalami penderitaan emosional dan psikologis. Penderitaan-penderitaan ini bertambah lagi ketika perempuan yang dijadikan harem tersebut adalah perempuan kaya, dia akan menderita secara meterial. Mereka tidak bisa memiliki orang yang mengumpuli dengan sepenuhnya, tetapi harus berbagi dengan selirselir yang lain. Yang lebih menyedihkan adalah bahwa hubungan kedua belah pihak bukan didasarkan kepada rasa cinta dan kasih sayang, tetapi hubungan antara tuan dan budak, dimana budak tidak mempunyai hak apapun terhadap tuannya. Kondisi perempuan yang mengenaskan pada masa Abbasiyah ini membuat para orang tua merasa ketakutan apabila mempunyai anak-anak gadis karena fenomena perempuan-perempuan yang ada dimasyarakatnya bisa saja terjadi dalam keluarganya, apalagi kalau keluarga tersebut masuk dalam kategori kelas bawah. Salah seorang penyair menegaskan "kita bidup pada masa, ketika salah seorang dari kita harus menikabkan anak perempuannya dengan sebuah kuburan, ia benar-benar

21 Ahmad Nahrawi, Al-Imâm al-Syâfî̀...,78.

${ }^{22}$ Ibid. 
akan memperoleh seorang menantu terbaik." 23 Ungkapan ini menggambarkan bahwa kematian adalah nasib yang lebih baik disbanding dengan jika dinikahkan dengan nanti dijadikan sebagai selir atau budak pemuas seksual lelaki kaya.

Gambaran ini mirip dengan kondisi pada zaman jahiliyah, dimana orang tua merasa malu mempunyai anak perempuan, bahkan pada masa ini ada ditambah rasa ketakutan yang mendalam. Ini merupakan bukti nyata tentang genting dan pedihnya kehidupan yang dialami para perempuan yang bisa jadi mengalami penistaan dan penghinaan dan mereka tidak berdaya untuk melindungi diri mereka sendiri.

Perempuan pada rentang waktu ini tidak hanya dianggap sebagai objek pemuas nafsu seksual laki-laki, tetapi mereka dianggap sebagai manusia yang rendah dan menjijikan dan tidak layak diperbincangkan dalam forum-forum resmi. Anggapan terhadap para perempuan yang demikian rendah ini membuat mereka tidak mempunyai atau tidak diberi kesempatan untuk berkiprah dalam masyarakat. Stereotipe perempuan ini menyebar dalam masyarakat karena penilaian yang demikian juga dikemukakan oleh Khalifah Dinasti Abbasiyah, al-Mahdi. Dukungan pemerintah untuk merendahkan perempuan ini membuat orang-orang dengan leluasa merendahkan perempuan tanda ada rasa takut terhadap pemerintah. Perempuan juga dianggap sebagai makhluk yang bodoh. Anggapan ini telah meminggirkan perempuan, dia tidak pernah diberi kesempatan untuk turut serta dalam urusan pemerintahan dan kedinastian. Pekerjaan perempuan praktis berada pada wilayah domestik dan wilayah ritual. Kondisi demikian menjadikan perempuan tidak mengerti urusan kemasyarakatan yang ada disekitar mereka. Perempuan tidak dianggap mempunyai kapabilitas dalam melakukan pekerjaanpekerjaan yang dianggap sebagai pekerjaan laki-laki, sebagaimana yang terpetik dalam pesan Khalifah al-Manshur kepada pegawainya, 'Abd al"Aziz ibn Muslim "Janganlah kamu mengikutsertakan perempuan dalam urusanmu", pesan al-Manshur ini juga disampaikan kepada putranya sendiri, al-Mahdi. Perempuan hanya layak untuk menjadi pemuas seksual laki-laki dan kalau dia lebih beruntung, dia hanya layak mengurusi urusan kerumahtanggaan. Mereka tidak dianggap pantas untuk mengurusi masalah kemasyarakatan dan pemerintahan karena urusan tersebut merupakan bagian laki-laki. ${ }^{24}$ Sebaliknya tugas-tugas seorang isteri hanyalah melayani suami, memelihara anak dan mengatur urusan rumah

${ }_{23}$ Philip K. Hitti, History Arabs..., 414.

${ }^{24}$ Zaenul Mahmudi, Sosiologi..., 87. 
tangga sementara waktu luang mereka biasanya digunakan untuk memintal dan menenun. ${ }^{25}$

\section{Kesimpulan}

Ketika Nabi Muhammad SAW dinikahkan dengan 'Aisyah RA di kota Mekah oleh Abu Bakr, sebagaimana diutarakan dalam hadits riwayat 'Aisyah, tidak disebutkan adanya anjuran untuk meminta izin pada calon mempelai perempuan yang masih gadis. Apa yang diputuskan oleh wali, maka itu pula yang menjadi keputusan seorang anak. Namun setelah itu, muncul satu saat dimana Rasul menganjurkan untuk meminta izin kepada anak perempuan yang masih gadis jika walinya hendak menikahkannya. Perubahan hokum atau ajaran ini, yakni anjuran meminta izin perempuan, tentu tidak terlepas dari kondisi sosial masyarakat di mana Rasul tinggal di situ. Jika di kota Mekah, dimana masyarakatnya terkatagori sebagai masyarakat tipikal Hadarî, tentu para perempuannya lebih banyak berdiam diri di rumah, sehingga cuku ayahnya saja yang menentukan, meski tanpa harus terlebih dahulu meminta izin kepada anak perempuannya yang masih gadis. Hal ini tentu sangat berbeda dengan tipikal masyarakat Madinah yang merupakan masyarakat pertanian dengan tipikal lebih dekat kepada masyarakat Badaw $\hat{\imath}$, peran perempuan di wilayah publik lebih terbuka. Sehingga tingkat pergaulan dan informasi relatif lebih luas dibanding perempuan masyarakat Hadarî.

Berbeda dengan di zaman Rasul, kondisi perempuan sewaktu imam Syafi'i hidup sangat terpengaruh terhadap kondisi politik kekuasaan pada saat itu. Perempuan terbagi menjadi tiga kelas; kelas atas, menengah dan bawah. Jika pada perempuan kelas atas, dan ini minoritas kaum perempuan saat itu, hak-hak publik relativ terlindungi, namun tidak pada dua kelas lainnya. Wilayah domestik berkisar urusan kerumahtanggaan menjadi wilayah sentral perempuan. Sehingga informasi berkait "luar dapur” kurang dapat terjangkau. Sebaliknya, laki-laki berkiprah pada wilayah-wilayah publik, sehingga sangat wajar kiranya jika kemudian ada hak ijbar bagi seorang wali atau ayah, yang memang sudah mengenal dunia luar, terhadap anak perempuannya, yang memang hanya berhubungan dengan apa yang ada di dalam rumah. Menurut al-Syafi'i hak ijbar wali atas anak perempuannya dalam hal penentuan pasangan suaminya begitu dominan, anak perempuan tidak akan mendapat kebebesan dalam menentukan pasangannya selama belum menjadi janda. Namun demikian, menurut al-Syafi'i bagi seorang wali sangat dianjurkan

25 Philip K. Hitti, History Arabs...,416. 
untuk meminta izin kepada anak perempuannya yang masih gadis jika di dapati anak gadisnya sudah berusia bâligh (cakap hukum).

Dari uraian yang telah dipaparkan di atas dapatlah diambil simpulan kesejarahan yang dapat digunakan untuk prediksi proyektif, bahwa; "Semakin kuat peran perempuan di wilayah publik, maka hak Ijbar semakin lemah, sebaliknya semakin lemah peran perempuan di wilayah publik, maka hak Ijbar akan semakin kuat".

Oleh karenanya, jika kemudian hak Ijbar diinginkan semakin kuat, dibutuhkan satu rekayasa dan pengkondisian secara sosial di mana peran dan posisi perempuan hanya dibatasi dengan hal-hal yang berkaitan dengan wilayah domestik. Sebaliknya, jika diinginkan hak Ijbar semakin lemah, maka upaya rekayasa sosial yang menempatkan perempuan di wilayah publik niscaya dibutuhkan. Wallabu A'lam.

\section{Daftar Pustaka}

Abdurrahman. KHI Di Indonesia. Jakarta: Akademika Pressindo, 1995.

Asqalani (al), Ahmad b. Hajar. Fath al-Bâri Syarh Șaḅ̧̂̉ Muslim. Beirut: Dar Ma'rifah, $1379 \mathrm{H}$.

Departemen Agama RI. Al-Qur'an dan Terjemabannya. Bandung: CV Penerbit J-Art, 2014.

Hitti, Philip K. History Arabs. terj. R. Cecep Lukman Yasin dan Dedi Slamet Riyadi. Jakarta: Serambi, 2008.

http://digilib.uin-suka.ac.id, diakses pada tanggal 24 Januari 2015.

Jaziri (al), Abdurahman. Kitâb al-Fiqhu 'alâ Madhâhib al-Arba'ah. Beirut: Dar al-Fikr, 1999.

Mahmudi, Zaenul. Sosiologi Fikih Perempuan. Malang: UIN Malang Press, 2009.

Nawawi (al), Abu Zakariya Yahya b. Syaraf. Syarḥ Șaĥ̉h Muslim. Beirut: Dar Ihya' Turats al-Arabi, $1392 \mathrm{H}$.

Naysaburi (al), Muslim b. Hajjaj. Șahîh Muslim. Beirut: Dar al-Kutub al'Ilmiyah, 2013.

Salam, Ahmad Nahrawi Abdus. Al-Imâm al-Syâfî̀ fi Madhâbibi al-Qadìm wa al-Jadîd. terj. Usman Sya'roni. Jakarta: Penerbit Hikmah, 2008.

Syafi'i (al), Muhammad b. Idris. Al-Umm. CD al-Maktabah al-Syamilah.

Zahrah, Muhammad Abu. Târikh Madhâhib al-Islâmiyyah. Kairo: Dar Fikr al-Arabi, 2009.

Zuhayli (al), Wahbah. Al-Fighu al-Islâmî wa Adillatuh. Beirut: Dar al-Fikr, 1997. 